Research article

\title{
SCANNING ELECTRON MICROSCOPY ANALYSIS OF CHANGES OF HYDROXIAPATITE/POLY-L-LACTIDE WITH DIFFERENT MOLECULAR WEIGHT OF PLLA AFTER INTRAPERITONEAL IMPLANTATION
}

\author{
ĐORĐEVIĆ Ljubiša ${ }^{1 *}$, NAJMAN Stevo ${ }^{2}$, VASILJEVIĆ Perica ${ }^{1}$, MILJKOVIĆ \\ Miroslav $^{2}$, IGNJATOVIĆ Nenad ${ }^{3}$, USKOKOVIĆ Dragan ${ }^{3}$, PLAVŠIĆ Milenko ${ }^{4}$ \\ ${ }^{1}$ Department of Biology with Ecology, Faculty of Science and Mathematics, University of Niš, Serbia; \\ ${ }^{2}$ Scientific Research Center for Biomedicine, Faculty of Medicine, University of Niš, Serbia; \\ ${ }^{3}$ Institute of Technical Sciences of the Serbian Academy of Sciences and Arts, Belgrade, Serbia; \\ ${ }^{4}$ National Academy of Engineering of Serbia, Belgrade, Serbia.
}

(Received 18 March; Accepted 24 May 2016)

Implantation of a biomaterial is one of the important trends in solving the problem of bone tissue loss. Calcium hydroxiapatite (HAp), as the most representative bone component is a serious candidate for such implantations. The synthetic polymer poly-L-lactide (PLLA) in HAp/PLLA is often used as a polymeric material, with a role in the substitution of bone tissue collagen fibers. Fibers of PLLA may strengthen HAp and its good bioresorption provides space for tissue remodeling. Differences in porosity, microstructure, compressive consistency as well as bioresorbility of HAp/ PLLA may be achieved by using PLLA with different molecular weights. In this study HAp/PLLA composites with PLLA of different molecular weights $(50,000 ; 160,000$ and 430,000$)$ were implanted in mouse peritoneum in order to examine the influence of the molecular weight of PLLA on morphology changes. Microstructural changes of biomaterial (HAp/PLLA) surface were analyzed one week, three weeks and four months after their implantation using Scanning Electron Microscopy. The results showed a significant difference in tissue reactions on the applied biocomposites, depending on their molecular weight. The most intense proliferation of cells was induced by HAp/PLLA 50,000 compared to HAp/PLLA 430,000 and HAp/PLLA 160,000. In the vicinity of HAp/PLLA 430,000 abundant erythrocytes were observed. The differences in biological reactions on the examined biocomposites are significant for their practical applications. HAp/PLLA composite biomaterials of different types and resorption rates require specific designing and programming to become suitable for particular purposes in an organism.

Key words: calcium hydroxiapatite, poly-L-lactide, implant, mouse, peritoneum, collagen, SEM

Corresponding author: e-mail: ljupce@pmf.ni.ac.rs 


\section{INTRODUCTION}

The best classical way for healing bone fracture is pelvic bone autografting. However, the autografting procedure is time consuming, expensive and increases the risks for the patient [1]. On the other side, the use of allografts or xenografts is accompanied by disadvantages such as unpredictable structure and mechanical strength, and a risk of transmission of infectious diseases. Artificial bone substitutes can solve many problems associated with the transplantation procedure [2]. Therefore, biocompatible materials have been introduced as substitutes for natural bone. Today, many indications require bone substitution such as: bone defects, osteoporotic fractures, spinal fusion, revision surgery etc. Thanks to the research progress of bioactive ceramics, they are increasingly in use due to their good biocompatibility, degradability, osteogenic potential and noticed interaction with cells [3].

Since natural bone consists of approximately $70 \%$ calcium phosphate apatite, hydroxyapatite (HAp) is characterized by good biocompatibility and is known as one of the most important implantable materials [4,5]. However, HAp often has a low strength and brittleness, so, combinations with polymers are recommended. Synthetic polymer poly-L-lactide (PLLA) is often used for combining with HAp [6,7]. Fibers of PLLA may strengthen HAp and its good bioresorbability provides space for tissue extension [8]. Composite biomaterial HAp/PLLA embodies good features of each of these biomaterials [9]. Differences in porosity, microstructure, compressive consistency as well as bioresorbability of HAp/PLLA may be achieved by using PLLA with different molecular weights [10-12].

Careful evaluation of new materials is necessary in order to affirm they have the desired healing characteristics. Intraperitoneal implantation is a good model for testing some important characteristics of biomaterials as biocompatibility, bioresorbtion, biomaterial-tissue interaction and other biofunctional properties. Moreover, the intraperitoneal method is very fast and implantations are easy to handle. The aim of our study was to examine the influence of molecular weight of PLLA on surface changes of intraperitonealy implanted HAp/PLLA biocomposites using Scanning Electron Microscopy.

\section{MATERIAL AND METHODS}

\section{Biomaterials}

HAp/PLLA composite biomaterial was prepared by cold pressing of the HAp and PLLA making blocks. In all cases, HAp/PLLA with 80 mass $\%$ HAp and 20 mass $\%$ PLLA was used. HAp was synthesized as high crystal phase. PLLA was synthesized by polymerization of L-lactide in three different molecular weights: 50,00; 160,000 and 430,000 $\mathrm{g} / \mathrm{mol}$. Therefore, in our experiments, PLLA was marked according to molecular weight as: PLLA(50), PLLA(160) PLLA(430). Biocomposites were 
prepared as cylindric forms with $5 \mathrm{~mm}$ in height and $1.5 \mathrm{~mm}$ in diameter, to facilitate implantation.

\section{Animals}

Sixty syngeneic Balb/c mice (male and female, 3 months old with body weight of 24$26 \mathrm{~g}$ ) were used in accordance with the principles of the Care and Use of Laboratory Animals and approved by the Ethical Committee of the Faculty of Medicine, University of Niš.

\section{Implantation}

The tested biomaterial was entered into the suprapubic part of mouse peritoneum with a sterile wide needle. Before implantation, the skin was disinfected with alcohol and after implantation antibiotics were given intraperitonealy. Removal and analysis of the implants was performed one week, three weeks and four months after their implantation.

\section{SEM}

Microstructure and surface characteristics of biocomposite samples after implantation were studied by scanning electron microscopy (SEM) using a JEOL JSM5300. In the SEM preparation, the samples were fixed in $0.4 \%$ glutaraldehyde for $24 \mathrm{~h}$, and then washed with $0.2 \mathrm{M}$ PBS ( $\mathrm{pH}$ from 7.2 to 7.4). Postfixation was performed with 1\% osmium tetroxide in a veronal buffer ( $\mathrm{pH}$ from 7.2 to 7.4 ) for 2 hours. Fixed samples were dehydrated in graded concentrations of alcohol followed by acetone. Before microscoping, samples were dried in $\mathrm{CO}_{2}$ at a critical point, and coated with gold in a vacuum evaporator.

\section{RESULTS}

\section{Implants after one week}

Connective tissue cells and fibers dominated on the surface of the HAp/PLLA(50) implant (Fig. 1). Cells and fibers penetrate from the surface into depth of the implant so, the whole implant looks infiltrated with collagen fibers and different cell types. The fibers are grouped in bundles sporadically (Fig. 1C). Cells are clustered over hollows, canals and cracks of implants (Fig. 1A and C). The granules of HAp are the places of cell adherence (Fig. 1D). PLLA squamae are sporadically mixed with collagen fibers (Fig. 1C). HAp surface looks degraded (Fig. 1D). HAp/PLLA(50) implants after one week are well wrapped in the capsule abundant with cells. There is no clear border between the capsule and the implant, so the inner layers of the capsule pervade the implants. 

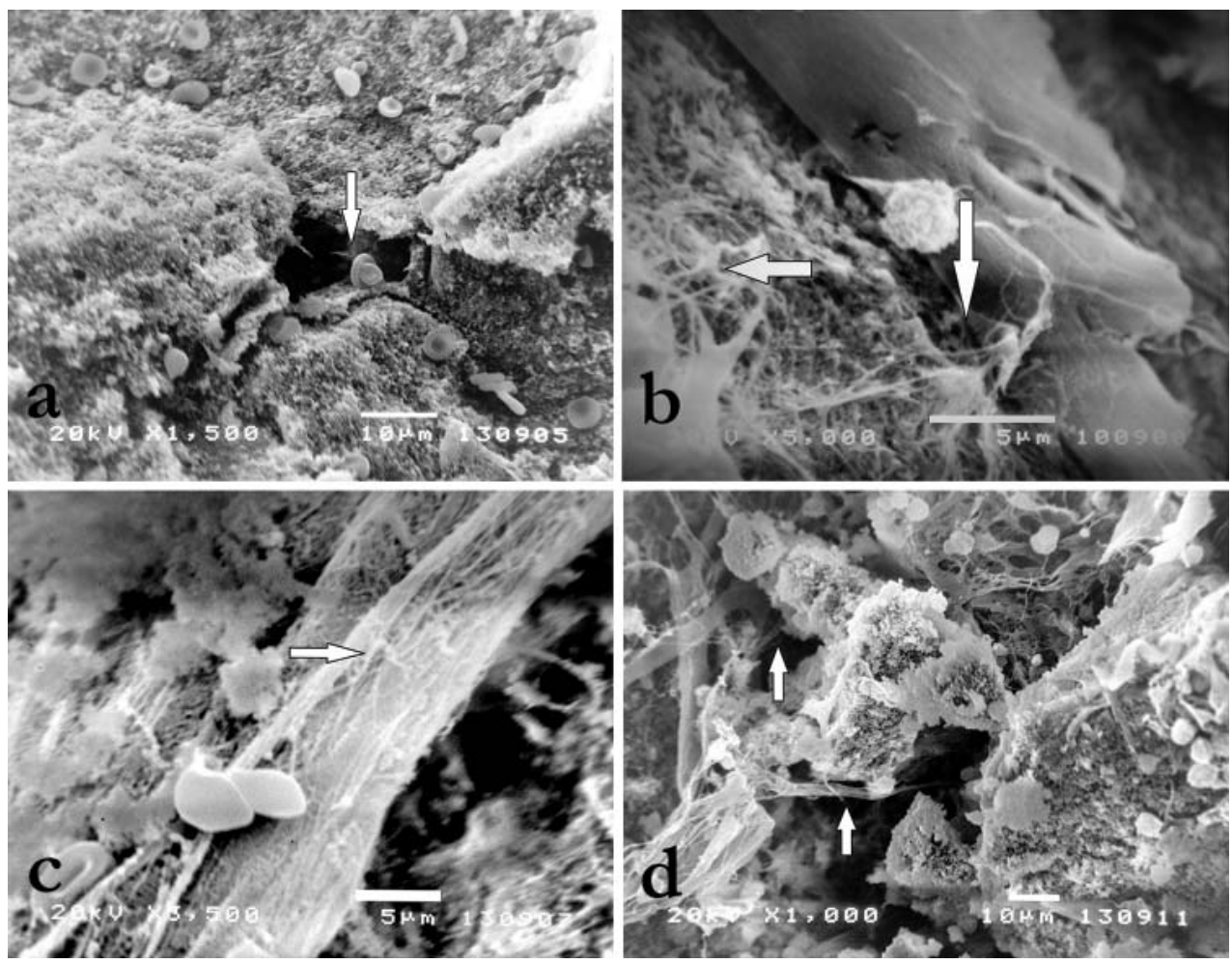

Figure 1. SEM micrograph of HAp/PLLA(50) implants after one week. There is good cellular response and prominent forming of collagen fibers. Erythrocytes were seen in implant hollow (A). PLLA is in close contacts with forming connective tissue (B and C). Connective tissue penetrates into the implant (D).

Unlike HAp/PLLA(50), after one week HAp/PLLA(160) implants are characterized with very rare cells and fibers on the surface, as well as inside.

On the surface and inside of HAp/PLLA(430) implants, adherent cells, collagen fibers and erythrocytes, which are the dominant cell population, are noticed. Mainly, collagen fibers look scattered, and are not abundant (Fig. 2). It is also recorded that some of them penetrate from the surface into the interior of the implants. In the hollows of this type of implants, there are groups of erythrocytes sporadically mixed with rare collagen fibers. Examined HAp/PLLA(430) implants are not wrapped in a capsule.

\section{Implants after three weeks}

In comparison with implants after one week, three weeks after implantation, HAp/ PLLA(50) implants are impregnated with an abundant network of fibers and heterogeneous cell types. In the fibers and cells network, sheets of different shape and squamae of PLLA are cached (Fig. 3). In addition, the formation of a capsule around implants could be seen. 

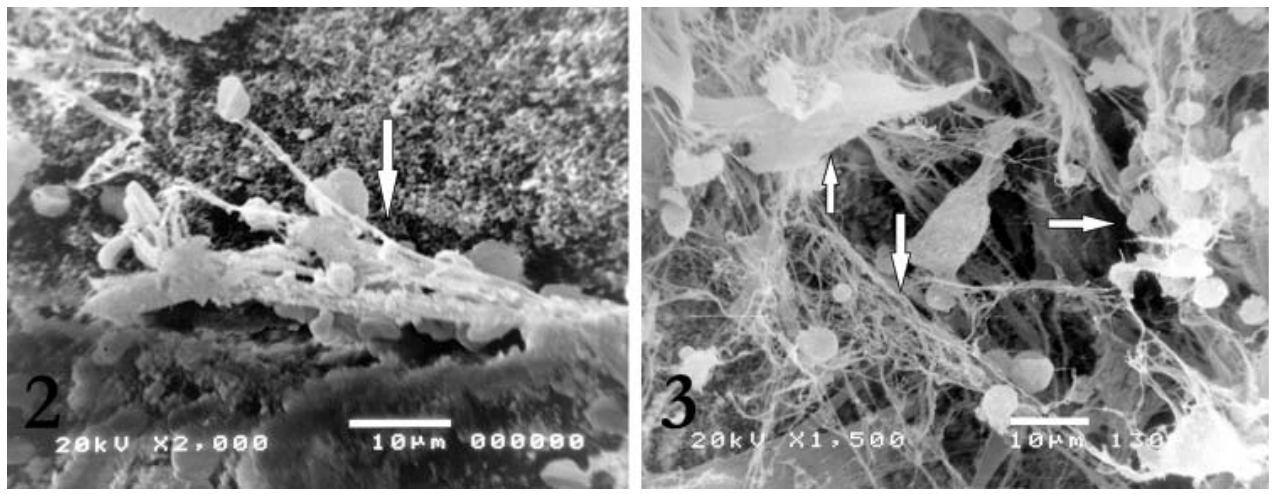

Figure 2. SEM micrograph of HAp/PLLA(430) implants after one week. In the cracks of implants erythrocytes, other types of cells and collagen fibers are noticed.

Figure 3. SEM micrograph of HAp/PLLA(50) implants after three weeks. Heterogeneous cell types, scattered fibers and PLLA squamae are observed.

Degraded surfaces which are covered by few cells and fibers characterize HAp/ PLLA(160) implants three weeks after implantation (Fig. 4A). The forming capsule with dense fibers and cells is visible and HAp particles are found inside it (Fig. 4B).

The breach of cells and fibers from the surface into the inside of HAp/PLA(430) implants are visible after three weeks of implantation. However, the penetration is not deep. The interior of implants is without cells and fibers. A thin capsule is formed around the implants. Dense cells sporadically lie below the capsule and over the implant surface (Fig. 5).
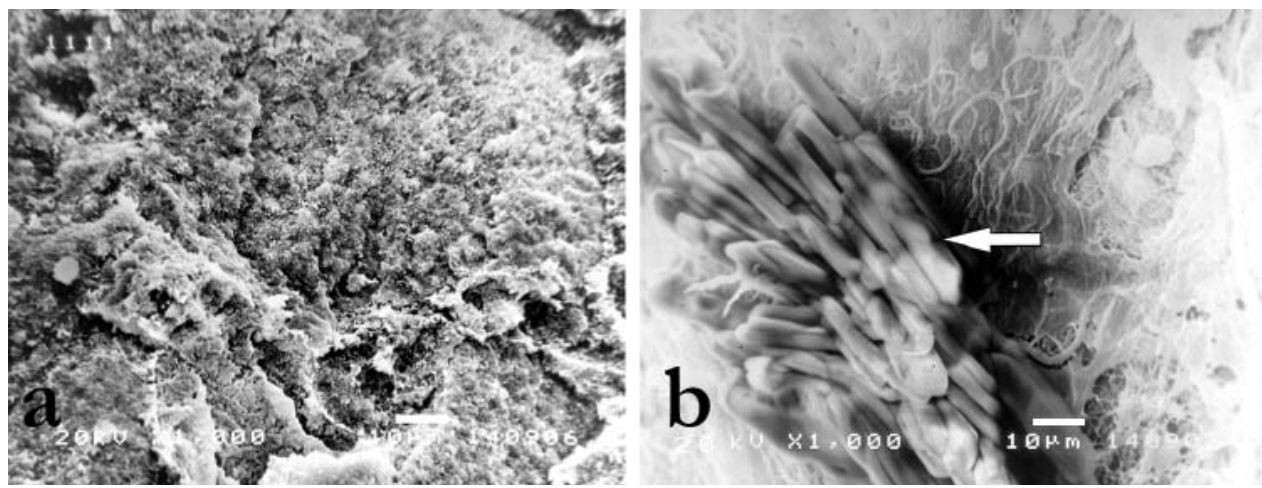

Figure 4. SEM micrograph of HAp/PLLA(160) implants after three weeks. Degraded surface of implants (A) and HAp particles in the capsule (B) have been noticed.

\section{Implants after four months}

Numerous collagen fibers can be seen over HAp/PLLA(50) implants after four months (Fig. 6A). Detached PLLA sheets and squamae are in the processes of degradation (Fig. 6B). There are no cells in the depth of implants. Sparse cells are visible only over the implant surface. Thin connective tissue of the capsule contains only rare cells. 


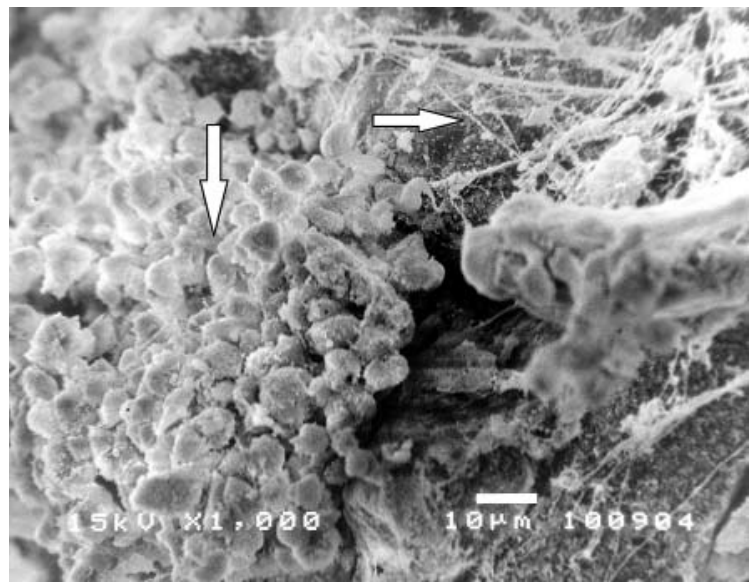

Figure 5. SEM micrograph of HAp/PLLA(430) after three weeks. Compact cell clusters and scattered fibers over implants are visible.

Sparse cells and rare fibers are noticed over the surface of HAp/PLLA(160) implants. A thin fibrous capsule, with a number of fiber bundles is noticed around the implants (Fig. 7A). Several fibroblast cells are found in the capsule. Collagen fibers make rare breaches from the surface into the implant.
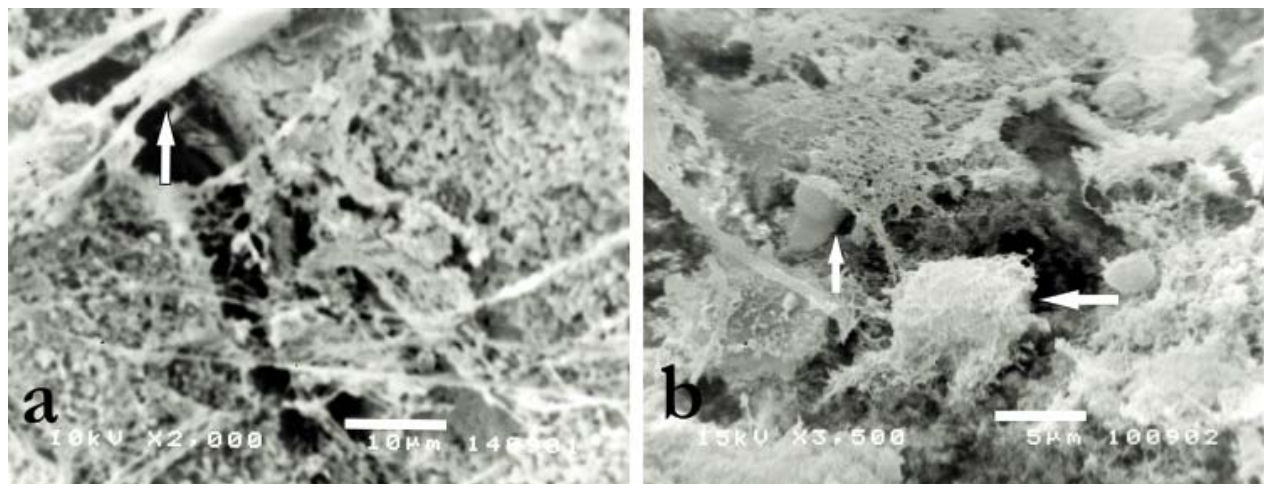

Figure 6. SEM micrograph of HAp/PLLA(50) implants after four months. Collagen fibers over a crack between implanted blocks and their degraded surface (A). Macrophages over perforated PLLA sheet (B).

HAp/PLLA(430) implants after four months are wrapped in a thick capsule consisting of intertwined fibers and numerous cells with a domination of fibroblasts (Fig. 7B). Collagen fibers and cells penetrate into the implants. Many collagen fibers are shared by the capsule and the interior of the implant. At the surface of the implants, adherent groups of cells can be noticed. 

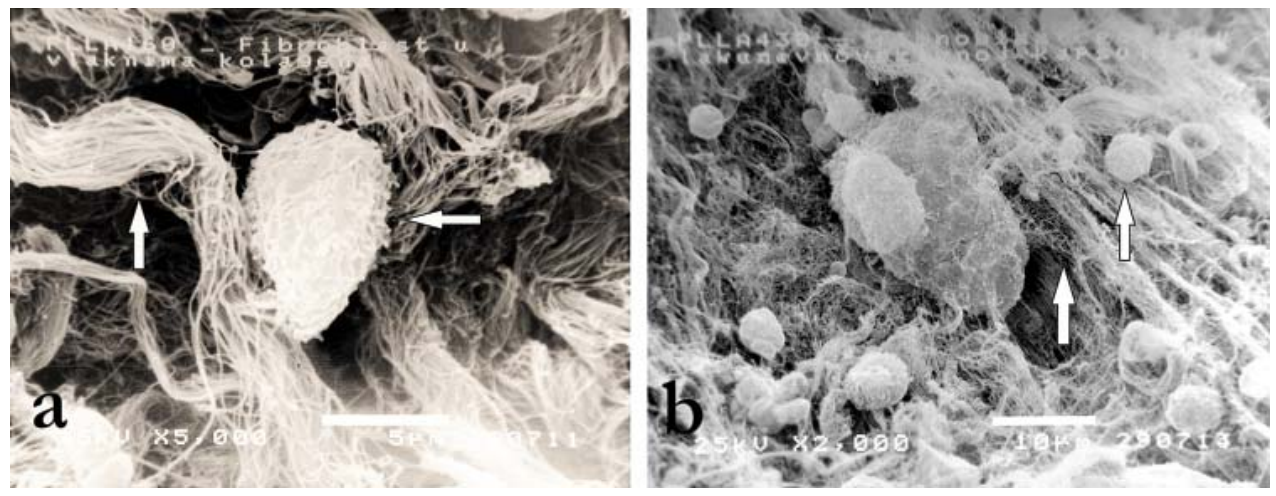

Figure 7. SEM micrograph of HAp/PLLA(160) implants after four months. Fibroblast in fiber bundles of the implant capsule (A). SEM micrograph of HAp/PLLA(430) after four months. Fibroblast fiber network in the capsule wraps the implant (B).

\section{DISCUSSION}

The most important requirements for implantation are acceptance of the biomaterial by an organism and reduction of negative responses to a minimum. Essential properties of the biomaterial used in live tissues are: not to be toxic, not to make chronic inflammatory processes, not to be cancerogenic, and not to induce allergic reactions.

Many results show that HAp/PLLA biocomposites possess good biocompatibility [12-14]. However, many studies have found that composition, particularly PLLA molecular weight, determines the fate of the biocomposite implant in the tissue. Also, one study showed that PLA/HAp composites were superior relative to pure PLA because of better protein adsorption and cell attachment. Induction of actin stress fibers and vinculin expression have also indicated the importance of the presence of HAp particles in the composite [15]. According to our results the most prompt cellular response characterizes implantation of HAp/PLLA(50) biocomposites. because these types of implants possess the most abundant cellular content (Fig.1; Fig.3). It was shown by FT-IR analysis that bioresorption of $50000 \mathrm{~g} / \mathrm{mol}$ PLLA took place much faster then PLLA of $430000 \mathrm{~g} / \mathrm{mol}$. [12]. Understanding of degradation characteristics of biomaterials is very important for biomedical application. Hydrolytic degradation of our biocomposites is very slow. PLLA component degrades faster inside then at the surface of sample. One of the reasons for this phenomenon is the specific distribution of carboxyl groups. There are more terminal carboxyl groups inside of PLLA material then outside, and carboxyl groups affect degradation autocatalitically. In vivo, degradation is performed by tissue enzymes, body liquids, and surrounded cells. So, degradation of HAp/PLLA biocomposites is a complex multifactorial process. 
Anyway, the status of the implant depends on the interaction between the implant and the tissue. In a study of cylindrical subcutaneous implants of poly-L-lactide, poly-L/ D-lactide and poly- L/DL-lactide the reduction in molecular mass of the implants was most intense one month after implantation, but none of the polymers was completely resorbed within a year [17]. Our results also show that phagocytosis still persists four months after implantation (Fig. 6).

In our previous experiment tissue reaction on HAp/PLLA was manifested by the formation of the capsule around the implant and the presence of fibroblast, macrophages, polymorphonuclear cells and cells characteristic for foreign body reaction [14]. Similar to, observations of our previous study, this research also revealed more intense cell reaction to the implant around composites that endured a faster decomposition.

As early as one week after implantation of HAp/PLLA(50), it was noticed that the whole implant had been infiltrated with collagen fibers and different cell types. It is obvious that present fibroblasts produce collagen. FT-IR analysis has shown that HAp/PLLA(50) blocks in vivo induced collagen synthesis three weeks after implantation [12]. The origin of collagen is questionable, but current experiments may indicate that collagen fibers are originated from the surrounding tissue. Similar findings were reported by researchers in other animals using a variety of implants, which indicates a general biological reaction to the implant [18].

The presence of erythrocytes in the HAp/PLLA(430) implants indicate that blood vessels are also present. The pronounced vascularization of this type of implants was observed on histology preparations [14]. It is known that angiogenesis represents one of the initial indications of tissue reparation, which makes this biocomposite a good candidate-material for bone reparation.

Since the tested HAp/PLLA materials differ only in PLLA molecular weight, differences in implant appearance and tissue reactions on tested biocomposites, probably depend on their molecular weight. The most intense proliferation of cells was induced by HAp/PLLA (50) implants, in comparison with HAp/PLLA (430) and HAp/PLLA (160). Abundant erythrocytes were observed in the vicinity of HAp/ PLLA (430) which indicates the most intensive process of angiogenesis in this type of implant. That could be important for their practical application HAp/PLLA composite biomaterials of different types and resorption rates require specific designing and programming to become suitable for particular purposes in an organism.

\section{Acknowledgements}

This study was supported by the Ministry of Education, Science and Technological Development of Republic of Serbia, Project Grants III 41017 and III 45004.

The authors are particularly grateful to the recently deceased professor Vojin Savić who as head of the Institute for Biomedical Research Faculty of Medicine made a great contribution to the joint study. 


\section{Authors' contributions}

LjĐ participated in designing and performing animal study as well as preparing manuscript. SN contributed to designing animal study, performing animal experiments, SEM analysis and preparing manuscript. PV contributed to manuscript preparation. MM carried out preparation of samples for SEM analysis as well as participating in SEM analysis. NI participated in material designing and synthesis as well as in manuscript preparation. DU contributed to material designing and synthesis. MP participated in material designing and synthesis. All authors read and approved the final manuscript.

\section{Declaration of conflicting interests}

The author(s) declared no potential conflicts of interest with respect to the research, authorship, and/or publication of this article.

\section{REFERENCES}

1. Keating FJ, McQueen MM. Substitutes for autologous bone graft in orthopaedic trauma. J Bone Joint Surg 2001; 83(1): 3-8.

2. Lazić Z, Bubalo M, Milović R, Matijević S, Magić M, Đorđević I. Comparison of resorbable membranes for guided bone regeneration of human and bovine origin. Acta VeterinariaBeograd 2014; 64(4): 477-492.

3. Gao C, Deng Y, Feng P, Mao Z, Li P, Yang B, Deng J, Cao Y, Shuai C, Peng S. Current progress in bioactive ceramic scaffolds for bone repair and regeneration. Int J Mol Sci 2014; 15: 4714-4732.

4. Kurashina K, Kurita H, Takeuchi H, Hirano M, Klein C, de-Groot K. Osteogenesis in muscle with composite graft of hydroxyapatite and autogenous calvarial periosteum: A preliminary report. Biomaterials 1995; 16(2): 119-123.

5. Ripamonti U, Duneas N. Tissue engineering of bone by osteoinductive biomaterials. MRS Bulletin 1996; 21(11): 36-42.

6. Angelova N, Hunkeler D. Rationalizing the design of polymeric biomaterials. Trends in Biotechnology 1999; 17(10): 409-421.

7. Wang Z, Wang Y, Ito Y, Zhang P, Chen X. A comparative study on the in vivo degradation of poly(L-lactide) based composite implants for bone fracture fixation, Scientific Reports 2016; 9;6:20770

8. Yanagida H, Okada M,Masuda M, Narama I, Nakano S, Kitao S, Takakuda K, Furuzono T. Preparation and in vitro/in vivo evaluations of dimpled poly(l-lactic acid) fibers mixed/ coated with hydroxyapatite nanocrystals. Journal of Artificial Organs 2011; 14, 331-341.

9. Freed L E, Vunjak-Novakovic G, Biron R J, Eagles D, Lesnoy D, Barlow S K, Langer R. Biodegradable polymer scaffolds for tissue engineering. Nature Biotechnology 1994; 12 : 689-693.

10. Ignjatović N, Tomić S, Dakić M, Miljković M, Plavšić M, Uskoković D. Synthesis and properties of hydroxyapatite/poly-L-lactide composite biomaterials. Biomaterials 1999; 20(9): 809-816. 
11. Nejati E, Firouzdor V, Eslaminejad M B, Bagheri F. Needle-like nano hydroxyapatite/ poly(L-lactide acid) composite scaffold for bone tissue engineering application. Materials Science and Engineering C 2009; 29: 942-949.

12. Ignjatović N, Savić V, Najman S, Plavšić M, Uskoković D. A study of HAp/PLLA composite as a substitute for bone powder, using FT-IR spectroscopy. Biomaterials 2001; 22(6): 571-575.

13. Najman S, Đorđević Lj, Savić V, Ignjatović N, Plavšić M, Uskoković D. Changes of HAp/PLLA biocomposites and tissue reaction after subcutaneous implantation. Facta Universitatis Series: Medicine and Biology 2003; 10(3): 131-134.

14. Najman S, Savic V, Djordjevic Lj. Ignjatovic N, Uskokovic D. Biological evaluation of hydroxyapatite/poly-L-lactide (HAp/PLLA) composite biomaterials with poly-L-lactide of different molecular weights intraperitoneally implanted into mice. Biomed Mater Eng 2004; 14(1): 61-70.

15. Persson M, Lorite SG, Kokkonen EH, Cho SW, Lehenkari PP, Skrifvars M, Tuukkanen J. Effect of bioactive extruded PLA/HA composite films on focal adhesion formation of preosteoblastic cells. Colloids and Surfaces B: Biointerfaces 2014; 121: 409-416.

16. Mansourizadeh F, Asadi A, Oryan S, Nematollahzadeh A, Dodel M, Asghari-Vostakolaei M. PLLA/HA Nano composite scaffolds for stem cell proliferation and differentiation in tissue engineering. Molecular Biology Research Communications 2013; 2(1-2): 1-10.

17. Mainil-Varlet P, Curtis R, Gogolewski S. Effect of in vivo and in vitro degradation on molecular and mechanical properties of various low-molecular-weight polylactides. J Biomed Mater Res 1997; 36(3): 360-80.

18. Podlaha J, Schwanhaeuser K. Experimental assessment of a new type of vascular prostheses with adiponectin (adipograft $\mathrm{Ra} 1 \mathrm{vk} \mathrm{7/350)}$ ) on sheep. Acta Veterinaria-Beograd 2014; 64(4): 426-437.

\title{
SKENIRAJUĆA ELEKTRONSKO MIKROSKOPSKA ANALIZA PROMENA HIDROKSIAPATIT/POLI-L-LAKTIDA SA RAZLIČITOM MOLEKULSKOM MASOM PLLA POSLE INTRAPERITONEALNE IMPLANTACIJE
}

\author{
ĐORĐEVIĆ Ljubiša, NAJMAN Stevo, VASILJEVIĆ Perica, MILJKOVIĆ Miroslav, \\ IGNJATOVIĆ Nenad, USKOKOVIĆ Dragan, PLAVŠIĆ Milenko
}

Jedan od bitnih pristupa u rešavanju problema gubitka koštanog tkiva danas predstavlja implantacija biomaterijala. Kalcijum hidroksiapatit (HAp), kao najzastupljenija komponenta kosti, je postao ozbiljan kandidat za implantacije. Sintetički polimer, poli -L-laktid (PLLA), se često koristi kao polimerni materijal u okviru HAp/PLLA kompozitnog materijala sa ciljem da zameni kolagena vlakna koštanog tkiva. Vlakna PLLA mogu da doprinesu čvrstini HAp dok njihova dobra biorazgradivost obezbeđuje prostor potreban za remodelaciju tkiva. Razlike u poroznosti, mikrostrukturi, kompre- 
sivnoj konzistenciji, kao i biorazgradivosti HAp/PLLA se mogu postići korišćenjem PLLA različitih molekulskih masa. U ovom radu, korišćen je HAp/PLLA kompozitni materijal sa PLLA komponentom različite molekulske mase (50 000, 160000 i 430 000) koji je implantiran u peritoneum miša. Promene u mikrostrukturi površine biometerijala (HAp/PLLA) su praćene jednu nedelju, tri nedelje i četiri meseca nakon njihove implantacije u peritoneum miša pomoću skenirajuće elektronske mikroskopije. Dobijeni rezultati pokazuju značajne razlike u reakciji tkiva na ispitivane kompozite, zavisno od njihove molekulske mase. Najintenzivnija proliferacija ćelija je uočena kod HAp/PLLA 50000 implanata u poređenju sa HAp/PLLA 430000 i HAp/PLLA 160 000. Obilje eritrocita se može primetiti u blizini HAp/PLLA 430000 implanata. Razlike u biološkoj reakciji na ispitivane materijale mogu biti značajne za različitu primenu biokompozita. Različiti tipovi HAp/PLLA kompozitnih biomaterijala sa različitom stopom resorpcije mogu biti napravljeni i programirani tako da budu pogodni za određene namene u organizmu. 